\title{
COVID-19 Salgınında Sağlık Çalı̧̧anlarının Stres Algı Düzeyinin Kas İskelet Sistemi Ağrılarına Etkisi
}

\author{
(iD) Sibel Gayretli Atan¹, (iD) Mesut Arslan², (iD) İsmail Palalı
}

${ }^{1}$ Öğr. Gör., Harran Üniversitesi, Sağıık Hizmetleri MYO, Tıbbi Hizmetler ve Teknikler Bölümü, Şanlıurfa, Türkiye

2 Öğr. Gör., Gümüşhane Üniversitesi, Sağlık Hizmetleri MYO, Terapi ve Rehabilitasyon Bölümü, Gümüşhane, Türkiye

${ }^{3}$ Öğr. Gör., Harran Üniversitesi, Sağlık Hizmetleri MYO, Terapi ve Rehabilitasyon Bölümü, Şanlıurfa, Türkiye

Öz

COVıD-19 Salgınında Sağlık Çalıșanlarının Stres Algı Düzeyinin Kas İskelet Sistemi Ağrılarına Etkisi

Amaç: Bu araștırma, COVID-19 salgınında sağlık çalışanlarının stres algı düzeyinin kas iskelet sistemi ağrılarına etkisinin değerlendirilmesi amacıyla planlandı.

Yöntem: Araștırmaya COVID-19 sürecinde sağlık alanında çalışan ve çalıșmaya gönüllü olarak katılan 232 birey alındı. Çalıșmaya katılan bireyler, Demografik Bilgi Formu, Algılanan Stres Ölçeği ve Nordic Kas İskelet Sistemi Anketinden olușan bir değerlendirme formu ile değerlendirildi. Değerlendirme formu Google formlar uygulaması üzerinden olușturuldu. Veriler internet üzerinden Whatsapp ve e-posta yoluyla toplandı. Nicel bağımsız verilerin analizi için Ki Kare test ve T test kullanıldı. Tüm analizler için anlamlılık düzeyi p<0,05 olarak kabul edildi

Bulgular: Çalıșmaya 96 erkek $(\% 53,4)$ ve 110 kadın $(\% 46,6)$ olmak üzere 206 kiși dahil edildi. Katılımcıların yaș ortalaması 32,71土 7,55 yıl idi. Katılımcıların 85’i (\%41,3) Hekim, 56'sı (\%27,2) Fizyoterapist, 26’sı (\%12,6) Hemșire/Ebe ve 30'u (\%14,6) Sağlık Teknikeri idi. Algılanan stres düzeyi ile son 12 ay ağrı, son 12 ay ağrıdan kaynaklı iș engeli ve son 7 gün ağrı varlığı karșılaștırıldığında sadece son 12 ay ve son 7 gün bel ağrısı ve son 7 gün el bilekleri/eller ağrısı ile algılanan stres düzeyi arasında anlamlı ilișki bulundu (sırasıyla $p=0,039, p=0,013, p=0,047$ ). Algılanan stres düzeyi ile tanımlayıcı parametreler arasında anlamlı bir ilișki bulunmadı. Son 7 gün el bilekleri/eller ağrısı ile tanımlayıcı parametreler karșılaștırıldığında sadece cinsiyet ile anlamlı bir ilișki bulundu $(p=0,023)$.

Sonuç: Bu çalıșmada COVID-19 ortamında çalıșan sağlık personellerinde el/ el bileği ve bel ağrısının stresle ilișkili olduğuna dair bulunan sonuçlar literatüre katkı sağlayacaktır. Bu konuda yapılan çalıșmaların sayısı oldukça azdır. Gelecekte popülasyonu yüksek olan çalışmalara ihtiyaç vardır.

Anahtar Kelimeler: COVID-19, Sağlık Çalışanları, Kas İskelet Sistemi Ağrıları, Algılanan Stres

\section{Abstract}

\section{The Effect of the Stress Perception Level of Health Care Workers on the Musculoskeletal Pain in the COVID-19 Outbreak}

Objective: This study was planned to evaluate the effect of the stress perception level of healthcare workers on musculoskeletal pain in the COVID-19 epidemic.

Methods: 232 individuals who worked in the field of health and participated voluntarily in the study during the COVID-19 process were included in the study. Individuals participating in the study were evaluated with an evaluation form consisting of the Demographic Information Form, the Perceived Stress Scale, and the Nordic Musculoskeletal System Questionnaire. The evaluation form was created on google forms application. Data were collected on the internet via WhatsApp and e-mail. Chi-square test and T test were used to analyze quantitative independent data. The level of significance was accepted as $p<0.05$ for all analyzes.

Results: 206 people, 96 men (53.4\%) and 110 women (46.6\%), was included in the study. The average age of the participants was $32.71 \pm 7.55$ year. Individuals participating in the study; 85 (41.3\%) were Physicians, 56 (27.2\%) were Physiotherapists, 26 (12.6\%) were Nurses / Midwives and 30 (14.6\%) were Health Technicians. According to the comparison of the perceived stress level was compared with pain in the last 12 months, work disability due to pain in the last 12 months, and presence of pain in the last 7 days, a significant relationship was found between the perceived stress level and low back pain in the last 12 months and last 7 days, and wrist / hand pain in the last 7 days. $(p=0.039, p=0.013, p=0.047$, respectively). There was no significant relationship between perceived stress level and descriptive parameters. When descriptive parameters were compared with wrist / hands pain in the last 7 days, a significant relationship was found only with gender $(p=0.023)$.

Conclusion: In this study, the results found that hand/wrist and low back pain are associated with stress in healthcare personnel working in the COVID-19 environment will contribute to the literature. The number of studies on this subject is very few. Studies with a high population are needed in the future.

Keywords: COVID-19, Health Workers, Musculoskeletal System Pains, Perceived Stress

Nasıl Atıf Yapmalı / How to Cite: Atan SG, Arslan M, Palalı İ. COVID-19 Salgınında Sağlık Çalıșanlarının Stres Algı Düzeyinin Kas İskelet Sistemi Ağrılarına Etkisi. MKÜ Tıp Dergisi. 2021;12(43):106-113. https://doi.org/10.17944/mkutfd.904051

Sorumlu Yazar/Corresponding Author: 0̈̆̆r. Gör. Mesut Arslan

Geliș/Received: 29 Mart.2021

Email: fzt.mesutarslan@gmail.com

Kabul/Accepted: 6 Nisan 2021

ORCID iD: 0000-0003-2880-2569 


\section{GíRis}

Koronavirüs hastalığı (COVID-19) 2019 yılı Aralık ayında Çin'in Wuhan kentinde ortaya çıkan ve hala devam eden salgın bir hastalıktır (1). Hastalığın yayılımı güçlü ve enfeksiyonu hızlıdır (2). Salgın yaklașık olarak 223 ülkeye yayılmıștır (3). Dünya Sağlık Örgütü'nün verilerine göre Dünya genelinde 10 Şubat 2021 tarihine kadar koronavirüs hastalığı bulunan insan sayısı 106.125.682 ve yaşamını kaybeden hastaların sayısı ise 2.320.497'dir (3). Türkiye genelinde ilk vaka 10 Mart 2020 tarihinde ortaya çıkmıștır. Sağlık Bakanlığı verilerine göre 10 Subat 2021 tarihine kadar toplam koronavirüse yakalanan hasta sayısı 2.548.195 ve vefat eden hasta sayısı ise 26.998'dir (4).

Hastalık, yakın temasta olan kișiler arasında kolaylıkla bulașabilir (5). Enfekte olan hastalarda bașlangıçta ateș, öksürük, burun tıkanıklığı ve yorgunluk gibi üst solunum yolu enfeksiyonları belirtileri gözlenir (6). Hastalık ilerledikçe nefes darlığı artmakta ve șiddetli akut solunum yolu enfeksiyonları ortaya çıkmaktadır $(6,7)$. Ağır vakalarda akut solunum sıkıntısı, septik şok, metabolik asidoz ve koagülasyon problemleri ölüme neden olmaktadır (7). Bu kritik durumla karșı karșıya kalan hastaların tanı, tedavi ve bakımıyla doğrudan ilgilenen sağlık personelinde psikolojik sorunlar, anksiyete ve depresyon gibi sağlık sorunları gelișme riski bulunmaktadır (8). Araştırmalar bu sağıık çalışanlarının yüksek stres seviyelerine sahip olduklarını göstermiștir (9). Literatürde fiziksel, psikososyal, kültürel ve kișisel faktörlerin Kas İskelet Sistemi HastaIıklarına (KiSH) neden olduğu belirtilmektedir (10). Kas İskelet Sistemi Hastalıkları ile psikolojik faktörler arasında güçlü bir ilișki vardır (11) ve bu faktörlerin kronik kas iskelet sistemi ağrılarının olușmasında önemli bir rolü olduğu düșünülmektedir (12). Salgın ortamında çalıșan sağlık personellerinde yoğun çalıșma saatleri, hastalığa yakalanma veya hastalığı aile bireylerine bulaștırma endișesi büyük bir stres olușturmaktadır. Yüksek psikolojik strese maruz kalan sağlık çalışanlarında KiSH görülmesi beklenen bir durumdur. Literatürde sağlık çaIışanlarında KiSH ve psikolojik stres arasındaki ilișkiyi inceleyen çalıșmalar mevcuttur (13). Ancak COVID-19 ortamında bu parametreleri değerlendiren herhangi bir çalıșmaya rastlanılmamaktadır. Bu nedenle bu çalıșmada COVID-19 ortamında çalıșan sağlık personellerinde algılanan stres seviyesi ve KisH değerlendirildi.

\section{GEREÇ VE YÖNTEM}

Araștırma, tanımlayıcı ve kesitsel bir çalıșmadır. Araștırmaya COViD-19 sürecinde sağlık alanında çalıșan ve çalıșmaya gönüllü olarak katılan 232 birey alındı. Anket formunda eksik bilgi bulunan ya da farklı meslek mensupları tarafından doldurulan 26 birey araștırmaya dahil edilmemiş olup araştırma 206 birey ile tamamlandı. Araștırma örneklem büyüklüğünü hesaplamak için $\mathrm{G}^{*}$ power 3.1.9.2 programı kullanıldı. Çalışmanın gücü $\% 95, \alpha=0.05$ ve korelasyon katsayısı 0.3 alındığında 134 olarak hesaplandı. Konu ile alakalı bu alanda yapılmıs prospektif benzer bir çalıșma olmadığı için etki büyüklüğü Cohen'in etki büyüklüğü tablosundan orta etki büyüklüğü olan 0.3 olarak alınmıștır (14).

\begin{tabular}{|c|c|c|c|c|}
\hline \multicolumn{2}{|c|}{ Tanımlayıcı Veri } & \multirow[t]{2}{*}{$n$} & \multirow[t]{2}{*}{$\%$} & \multirow{2}{*}{$\begin{array}{c}\text { Ort. } \pm \text { ss } \\
32,71 \pm 7,55\end{array}$} \\
\hline Yaș & & & & \\
\hline \multirow[t]{2}{*}{ Cinsiyet } & Kadın & 110 & 46,6 & \\
\hline & Erkek & 96 & 53,4 & \\
\hline \multirow[t]{2}{*}{ Medeni Durum } & Bekar & 86 & 41,7 & \\
\hline & Evli & 120 & & \\
\hline \multirow[t]{3}{*}{$\begin{array}{l}\text { Öğrenim } \\
\text { Durumu }\end{array}$} & Ön lisans & 23 & 11,2 & \\
\hline & Lisans & 111 & 53,9 & \\
\hline & Lisansüstü & 72 & 35,0 & \\
\hline \multirow[t]{5}{*}{ Meslek } & Hekim & 85 & 41,3 & \\
\hline & Fizyoterapist & 56 & 27,2 & \\
\hline & Hemşire/Ebe & 26 & 12,6 & \\
\hline & Sağlık Teknikeri & 30 & 14,6 & \\
\hline & Diğer & 9 & 4,4 & \\
\hline \multirow[t]{2}{*}{ Çalıștığı Sektör } & Kamu & 163 & 79,1 & \\
\hline & Özel & 43 & 20,9 & \\
\hline \multirow[t]{7}{*}{ Çalıștığı Birim } & $\begin{array}{l}\text { COVID Karantina } \\
\text { Ünitesi }\end{array}$ & 17 & 8,3 & \\
\hline & Acil Servis & 24 & 11,7 & \\
\hline & Yoğun Bakım & 15 & 7,3 & \\
\hline & Ameliyathane & 9 & 4,4 & \\
\hline & Poliklinik & 46 & 22,3 & \\
\hline & Aile Sağ|Iğı Merkezi & 10 & 4,9 & \\
\hline & Diğer & 85 & 41,3 & \\
\hline \multirow[t]{4}{*}{ Çalıșma Süresi } & $0-3$ yıl & 50 & 24,3 & \\
\hline & 4-10 yıl & 93 & 45,1 & \\
\hline & $11-20 y \mathrm{yl}$ & 41 & 19,9 & \\
\hline & 20 yıl üstü & 22 & 10,7 & \\
\hline \multirow[t]{2}{*}{$\begin{array}{l}\text { Sigara } \\
\text { Kullanımı }\end{array}$} & Kullanıyor & 33 & 16,0 & \\
\hline & Kullanmıyor & 173 & 84,0 & \\
\hline
\end{tabular}

Ort.: Ortalama, Ss: Standart sapma

\section{Veri Toplama Araçları}

Çalıșmaya katılan bireyler, Demografik Bilgi Formu, AlgıIanan Stres Ölçeği ve Nordic Kas İskelet Sistemi Anketinden oluşan bir değerlendirme formu ile değerlendirildi. Değerlen- 
dirme formu Google formlar uygulaması üzerinden olușturuldu. Veriler internet üzerinden Whatsapp ve e-posta yoluyla toplandı.

Demografik Bilgi Formu: Araștırmacılar tarafından olușturulan formda; bireylerin demografik özellikleri, meslek, çalıştığı sektör, çalıștığı birim, çalıșma süresi, sigara kullanımı ve COVID-19 ile ilgili bilgilerden olușan 15 soru yer almaktadır.

\section{Tablo 2: Algulanan Stres Dizzeyi ile Kas iskelet Sistemi} Ağriları Arasındaki iliş̧i

\begin{tabular}{|c|c|c|c|c|}
\hline \multicolumn{2}{|c|}{ Algılanan Stres Düzeyi } & $n$ & Ort. \pm ss & $p$ \\
\hline \multirow[t]{2}{*}{$\mathrm{Bel}^{1}$} & Evet & 137 & $31,72 \pm 4,03$ & $0,039 *$ \\
\hline & Hayır & 69 & $32,88 \pm 3,23$ & \\
\hline \multirow[t]{2}{*}{$\mathrm{Bel}^{2}$} & Evet & 64 & $31,38 \pm 3,84$ & 0,063 \\
\hline & Hayır & 142 & $32,44 \pm 3,77$ & \\
\hline \multirow[t]{2}{*}{$\mathrm{Be}^{3}$} & Evet & 104 & $31,46 \pm 4,05$ & $0.013^{*}$ \\
\hline & Hayır & 102 & $32,77 \pm 3,46$ & \\
\hline \multirow[t]{2}{*}{ Boyun' } & Evet & 134 & $32,40 \pm 3,80$ & 0,136 \\
\hline & Hayır & 72 & $31,57 \pm 3,80$ & \\
\hline \multirow[t]{2}{*}{ Boyun $^{2}$} & Evet & 54 & $32,72 \pm 4,73$ & 0,172 \\
\hline & Hayır & 152 & $31,89 \pm 3,43$ & \\
\hline \multirow[t]{2}{*}{ Boyun ${ }^{3}$} & Evet & 100 & $32,28 \pm 4,15$ & 0,540 \\
\hline & Hayır & 106 & $31,95 \pm 3,48$ & \\
\hline \multirow[t]{2}{*}{$\operatorname{Sirt}^{1}$} & Evet & 147 & $32,05 \pm 3,86$ & 0,735 \\
\hline & Hayır & 59 & $32,25 \pm 3,74$ & \\
\hline \multirow[t]{2}{*}{ Sirt ${ }^{2}$} & Evet & 46 & $32,28 \pm 3,61$ & 0,731 \\
\hline & Hayır & 160 & $32,06 \pm 3,88$ & \\
\hline \multirow[t]{2}{*}{ Sirt ${ }^{3}$} & Evet & 104 & $31,78 \pm 3,89$ & 0,207 \\
\hline & Hayır & 102 & $32,45 \pm 3,72$ & \\
\hline \multirow[t]{2}{*}{ Omuzlar ${ }^{1}$} & Evet & 114 & $32,13 \pm 3,82$ & 0,934 \\
\hline & Hayır & 92 & $32,09 \pm 3,83$ & \\
\hline \multirow[t]{2}{*}{ 0muzlar ${ }^{2}$} & Evet & 36 & $31,97 \pm 4,93$ & 0,810 \\
\hline & Hayır & 170 & $32,14 \pm 3,55$ & \\
\hline \multirow[t]{2}{*}{0 muzlar ${ }^{3}$} & Evet & 71 & $32,14 \pm 3,98$ & 0,937 \\
\hline & Hayır & 135 & $32,10 \pm 3,74$ & \\
\hline \multirow[t]{2}{*}{ Dirsekler ${ }^{1}$} & Evet & 26 & $32,46 \pm 3,42$ & 0,618 \\
\hline & Hayır & 180 & $32,06 \pm 3,88$ & \\
\hline \multirow[t]{2}{*}{ Dirsekler $^{2}$} & Evet & 13 & $31,46 \pm 3,28$ & 0,527 \\
\hline & Hayır & 193 & $32,16 \pm 3,85$ & \\
\hline \multirow[t]{2}{*}{ Dirsekler $^{3}$} & Evet & 20 & $32,85 \pm 2,70$ & 0,364 \\
\hline & Hayır & 186 & $32,03 \pm 3,91$ & \\
\hline
\end{tabular}


mektedir. Katılımcılar her maddeyi "Hiçbir zaman (0)" ilâ "Çok sık (4)" arasında değișen 5'li Likert tipi ölçek üzerinde değerlendirmektedir. Maddelerden olumlu ifade içeren 7'si tersten puanlanmaktadır. Anket puanları 0 ile 56 arasında değișmektedir. Yüksek puan kişinin stres algı düzeyinin yüksek olduğuna işaret etmektedir (16).

Nordic Kas iskelet Sistemi Anketi: Bu anket son 12 ay ve son 7 gün içinde dokuz farklı vücut bölgesinin (bel, boyun, sırt, omuzlar, dirsekler, el bilekleri/eller, kalçalar/uyluklar, dizler, ayak bilekleri/ayaklar) kas iskelet sistemi problemlerini değerlendirir. Anket, cevapları evet/hayır șeklinde sorgulanan 27 madde içerir (17). Nordic Kas-İskelet Anketi (NMQ), İskandinav Bakanlar Konseyi tarafından finanse edilen bir projeden geliştirilmiștir (18). Kahraman ve ark. tarafından Türkçe geçerlilik ve güvenilirliği yapılmıștır (17).

İstatistiksel Analiz

Tanımlayıcı verilerin istatistiksel dağılımı sayı (n) ve oran (\%) kullanılarak gösterildi. Nicel bağımsız verilerin analizi için Ki Kare test ve T test kullanıldı. İstatiksel analiz SPSS istatistik paket programı (IBM Statistic, 15.0. Chicago, IL, ABD) kullanılarak yapıldı. Tüm analizler için anlamlılık düzeyi $p<0,05$ olarak kabul edildi.

\section{Tablo 3: Alglanan Stres Düzeyi ile Tanımlayıc} Parametreler Arasındaki iliş̧i

\begin{tabular}{|c|c|c|c|c|}
\hline \multicolumn{2}{|c|}{ Algılanan Stres Düzeyi } & $\mathrm{n}$ & Ort. \pm ss & $p$ \\
\hline \multirow[t]{2}{*}{ Cinsiyet } & Erkek & 96 & $31,93 \pm 3,91$ & \multirow{2}{*}{0,518} \\
\hline & Kadın & 110 & $32,27 \pm 3,74$ & \\
\hline \multirow[t]{2}{*}{ Medeni Durum } & Bekar & 86 & $32,41 \pm 4,34$ & \multirow{2}{*}{0,349} \\
\hline & Evli & 120 & $31,90 \pm 3,39$ & \\
\hline \multirow[t]{2}{*}{ Sigara Kullanımı } & Kullanıyor & 33 & $31,52 \pm 4,39$ & \multirow{2}{*}{0,32} \\
\hline & Kullanmıyor & 173 & $32,23 \pm 3,70$ & \\
\hline \multirow[t]{2}{*}{$\begin{array}{c}\text { Kronik hastalı̆̆ınız var } \\
\text { mı? }\end{array}$} & Evet & 29 & $31,28 \pm 3,48$ & \multirow{2}{*}{0,204} \\
\hline & Hayır & 177 & $32,25 \pm 3,86$ & \\
\hline \multirow[t]{2}{*}{ Aileyle mi yașıyorsunuz? } & Evet & 135 & $32,24 \pm 3,61$ & \multirow{2}{*}{0,493} \\
\hline & Hayır & 71 & $31,86 \pm 4,19$ & \\
\hline \multirow{2}{*}{$\begin{array}{l}\text { Evde kronik hastalığı ya } \\
\text { da } 65 \text { yaş üzeri olan kiși } \\
\text { var mı? }\end{array}$} & Evet & 27 & $32,81 \pm 4,39$ & \multirow{2}{*}{0,306} \\
\hline & Hауıг & 179 & $32,01 \pm 3,72$ & \\
\hline \multirow[t]{2}{*}{$\begin{array}{l}\text { CoviD için yeterli kișisel } \\
\text { önlem alıyor musunuz? }\end{array}$} & Evet & 147 & $32,14 \pm 3,83$ & \multirow{2}{*}{0,885} \\
\hline & Hayır & 59 & $32,05 \pm 3,81$ & \\
\hline
\end{tabular}

Ort.: Ortalama, Ss: Standart sapma, $p<0,05$ olması anlamlılık düzeyi olarak kabul edilmiștir
Tablo 4: Son 7 Gün El bilekleri/Eller Ağrısı fle Tanımlayıc Parametreler Arasındaki ilişki

\begin{tabular}{|c|c|c|c|c|c|c|}
\hline \multirow{2}{*}{\multicolumn{2}{|c|}{$\begin{array}{l}\text { El bilekleri/Eller Ağrısı Varlığı } \\
\text { n }\end{array}$}} & \multirow{2}{*}{$\begin{array}{c}\text { Evet } \\
\%\end{array}$} & & \multirow{2}{*}{$\begin{array}{c}\text { Hayır } \\
\%\end{array}$} & \multirow[b]{3}{*}{42,2} & \\
\hline & & & $\mathrm{n}$ & & & \\
\hline Cinsiyet & Erkek & 9 & 4,4 & 87 & & \multirow{2}{*}{$0,023^{*}$} \\
\hline & Kadın & 23 & 11,2 & 87 & 42,2 & \\
\hline \multirow[t]{2}{*}{$\begin{array}{l}\text { Sigara } \\
\text { Kullanımı }\end{array}$} & Kullanıyor & 5 & 2,4 & 28 & 13,6 & \multirow[t]{2}{*}{0,947} \\
\hline & Kullanmıyor & 27 & 13,1 & 146 & 70,9 & \\
\hline \multirow{2}{*}{$\begin{array}{c}\text { Kronik } \\
\text { hastalığınız var } \\
\text { mı? }\end{array}$} & Evet & 4 & 1,9 & 25 & 12,1 & \multirow{2}{*}{0,780} \\
\hline & Hayır & 28 & 13,6 & 149 & 72,3 & \\
\hline \multirow[t]{2}{*}{$\begin{array}{c}\text { Aileyle mi } \\
\text { yașıyorsunuz? }\end{array}$} & Evet & 24 & 11,7 & 111 & 53,9 & \multirow{2}{*}{0,220} \\
\hline & Hауıг & 8 & 3,9 & 63 & 30,6 & \\
\hline \multirow[t]{2}{*}{$\begin{array}{c}\text { Evde kronik } \\
\text { hastalı̆̆ı ya da } \\
65 \text { yaș üzeri } \\
\text { olan kişi var } \\
\text { mı? }\end{array}$} & Evet & 5 & 2,4 & 22 & 10,7 & \multirow[t]{2}{*}{0,646} \\
\hline & Hауıг & 27 & 13,1 & 152 & 73,8 & \\
\hline \multirow[t]{2}{*}{$\begin{array}{l}\text { COVID için } \\
\text { yeterli kișisel } \\
\text { önlem alıyor } \\
\text { musunuz? }\end{array}$} & Evet & 21 & 10,2 & 126 & 61,2 & \multirow[t]{2}{*}{0,435} \\
\hline & Hayır & 11 & 5,3 & 48 & 23,3 & \\
\hline
\end{tabular}

Ort.: Ortalama, SS: Standart sapma, $p<0,05$ olması anlamlılık düzeyi olarak kabul edilmiștir.

\section{BULGULAR}

Çalıșmaya 96 erkek $(\% 53,4)$ ve 110 kadın $(\% 46,6)$ olmak

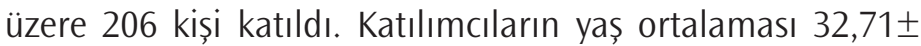
7,55 yıl idi. Katılımcıların 85’i (\%41,3) Hekim, 56’sı (\%27,2) Fizyoterapist, 26'sı $(\% 12,6)$ Hemșire/Ebe ve 30'u $(\% 14,6)$ SağIık Teknikeri idi. Katılımcıların 163'ü $(\% 79,1)$ kamu çalıșanı ve 156 'sı $(\% 75,7) 4$ yılın üstünde çalıșma süresine sahipti. KatıIımcıların tanımlayıc verileri Tablo 1'de gösterilmektedir.

Algılanan stres düzeyi ile son 12 ay ağrı, son 12 ay ağrıdan kaynaklı iș engeli ve son 7 gün ağrı varlığı karșılaștırıldığında sadece son 12 ay ve son 7 gün bel ağrısı ve son 7 gün el bilekleri/eller ağrısı ile algılanan stres düzeyi arasında anlamlı ilișki bulundu (sırasıyla $p=0,039, p=0,013, p=0,047$ ). Son 12 ay ve son 7 gün bel ağrısı olanların olmayanlara göre algılanan stres düzeyi daha düşük, son 7 gün el bilekleri/eller ağrısı olanların ise olmayanlara göre daha yüksek bulundu. Diğer 
vücut bölgeleri ile algılanan stres düzeyi arasında istatistiksel anlamlı bir ilișki gözlenmedi (Tablo 2).

Algılanan stres düzeyi ile tanımlayıcı parametreler arasında anlamlı bir ilișki bulunmadı (Tablo 3). Son 7 gün el bilekleri/eller ağrısı ile tanımlayıcı parametreler karşılaștırıldığında sadece cinsiyet ile anlamlı bir ilișki bulundu $(p=0,023)$. Kadınlarda ağrı varlığı daha yüksekti (Tablo 4).

\section{TARTIȘMA}

Kas iskelet siteminde en çok ağrı görülen bölgeler sırt, bel ve boyun bölgesi olarak tespit edilen bu çalıșmada algılanan stres düzeyi ile son 12 ay ağrı, son 12 ay ağrıdan kaynaklı iș engeli ve son 7 gün ağrı düzeyi arasındaki ilișki incelenmiștir. Bu incelemeye göre sadece son 12 ay ile son 7 gün bel ağrısı ve son 7 gün el bileği/eller ağrısı ile algılan stres arasında ilișki bulunmuștur.

Çalıșan bireylerde ağrının en sık rastlandığı bölgenin bel, boyun ve sırt ağrısı gibi omurgada görüldüğü çalıșmalarda bildirilmektedir $(19,20)$. Aynı șekilde bu çalışmada son 12 ay ağrısı, son 12 ay iș engeli ve son 7 gün ağrıda en yüksek insidansa bel, sırt ve boyun bölgeleri sahiptir. Analay Y. ve arkadașlarının yaptıkları çalışmada ofis çalıșanlarında ağrıdan en fazla etkilenen bölgenin bel olduğu bildirilmiștir (21). Skovlund S.V. ve arkadașlarının yaptığı çalıșmada, çalıșan popülasyonda kas iskelet sistemi ağrıları incelenmiş ve ağrının en sık görüldüğü bölgelerin bel ve boyun olduğu bulunmuștur (22). Davis K.G ve arkadașlarının hemșireler üzerinde kas iskelet sistemi rahatsızlıkları ile ilgili yaptıkları sistematik derlemede 12 aylık dönemde en çok ağrının bel, sırt ve omuz bölgesinde olduğu bildirilmiștir (23). Kas iskelet sitemi hastalıklarının literatürdeki prevelansına bakıldığında, genel popülasyonda bel ağrısı insidansının \%51-84 (yaşamları boyunca) arasında değiștiği gözlenmektedir. Son 12 ayda ise bel ağrısı insidansı \%39-67 arasında değișirken, son 1 ayda bel ağrısı yașayanların insidansının \%33 olduğu tespit edilmiștir (24). Bu çalıșmada da literatüre paralel olarak son 12 ayda bel ağrısı yașayanların oranı \%66,5 ve son 7 günde bel ağrısı yașayanların oranı ise \%50,4'tür. Şirzai ve arkadașlarının yaptığı bir çalıșmada, sağlık çalışanlarında üst ekstremitedeki rahatsızlıklar incelenmiș. Çalıșmaya göre son 12 ayda boyun ağrısı yaşayanların oranı \%50 ve son 7 günde boyun ağrısı yașayanların insidansı $\% 28$ iken son 12 ayda sırt ağrısı yaşayanların oranı \%47 ve son 7 günde sırt ağrısı yașayanların insidansı ise \%26'dır (25). Bu çalıșmada son 12 ayda boyun ağrısı yaşayanların oranı \%65, son 7 günde boyun ağrısı yașayanların oranı \%48 iken son 12 ayda sırt ağrısı oranı \%71 ve son 7 günde sırt ağrısı oranı $\% 5$ tir. Bu çalıșma sonuçlarının literatüre göre yüksek olduğu görülmektedir. COVID-19 nedeniyle iş yükü artışının ağrı görülme oranlarını da yükselttiği düşünülmektedir.

Stres, kișinin yüksek istekleri ve bu isteklerin karșılanamadığı zamanlarda ortaya çıkan duygusal ve fizyolojik tepkileri ifade etmektedir (26). Kas iskelet sitemi hastalıkları için değiștirilebilen bir risk faktörü olan stres bireylerin așırı uyarıcı olaylar karșısında biyolojik, psikolojik ve sosyal açıdan homeostazisini zorlayıp baș etme yeteneğini azaltan hormonal bir tepki mekanizmasıdır (27). Bu duruma bağlı olarak stres seviyesi ve sağlık arasında önemli bir ilișki vardır. Literatürde psikososyal faktörlerin KiSH ile direkt ilișkisi olduğu ve stresin azaltılmasının sağlık durumunun iyileşmesine neden olduğu belirtilmektedir (28). Algılanan Stres Ölçeğine göre 11-26 puan düșük stres düzeyi, 27-41 orta stres düzeyi ve 42-56 olması yüksek stres düzeyini göstermektedir (29). Bu çalıșmada bireylerin stres düzeyi ortalaması 32,11 olarak bulundu. Atanes ve arkadașlarının sağlık çalıșanları üzerinde yaptıkları çalışmada stres puanı ortalaması 42,2'dir (30). Tekin E ve arkadaşlarının farklı meslek düzeylerinde algılanan stresi değerlendikleri çalıșmada ise sağlık çalışanlarının ortalama stres puanı 31,08 bulunmuştur (31). Literatürde farklı sonuçların olduğu görülmektedir. Bu durumun örneklem büyüklügünün farklı olmasından kaynaklı olabileceği düșünülmektedir. Yüksek stres seviyesi birçok kas iskelet sistemi rahatsızlıklarının etiyolojilerinden biridir. Fakat Stres ve KiSH arasındaki ilișkiyi değerlendiren çalıșmalar çelișkili sonuçlar içermektedir (13, 32).

Literatürde Şirzai H. ve arkadașlarının yaptıkları çalışmada son 12 ayda el / el bileği ağrısı yașayanlarının insidansı \%24 ve son 7 günde el/el bileği ağrısı yașayanların oranı ise \%13’tür (25). Bu çalıșmada literatüre paralel olarak son 12 ayda el/ el bileği ağrısı yașayanların oranı \%30 ve son 7 günde el / el bileği ağrısı yașayanların oranı ise \%15,5'tir. Șirzai H. ve arkadașlarının yaptıkları bu çalıșmada el/el bileği ağrısı için erkek cinsiyet bir risk faktörüdür (25). Bu çalıșmada ise el/ el bileği ağrısı olan kișilerin \%71,8'i kadınlardan oluștuğu ve literatürden farklı olarak kadın cinsiyette olmak el /el bileği ağrısı için risk faktörü olduğu bulunmuștur. Șirzai H. ve arkadașları tarafından yapılan çalıșmada, hastanede temizlik personeli olarak çalıșan erkeklerin ağır kaldırma, daha yoğun ișlerde çalıșma ve el-el bileğine așırı yük bindirmelerinden kaynaklı daha fazla el/el bileği ağrısı çektikleri ifade edilmiștir (25). Bu çalıșmada kadınlarda daha fazla el/el bileği ağrısı olması, kadınların evde çocuk bakımı ve ev ișlerini yapmak gibi görevleri olduğundan ișten sonra dinlemek için yeteri kadar zaman ayıramamalarının neden olabileceği düșünülmektedir. Ayrıca kadınlarda ağrı eșiğinin daha düșük olmasının neden olabileceği düşünülmektedir (25).

Literatürde el/ el bileği ağrısı ve stres arasındaki ilișkiyi inceleyen sınırlı sayıda çalıșmaya rastlanmaktadır (33-35). ÇaIıșmalar ile ilgili olarak çelișkili sonuçlar mevcuttur. Mehrdad R. ve arkadașlarının yaptıkları çalıșmada orta stres seviyesine sahip hemşirelerin el bileği ve boyun bölgelerindeki ağrı ile stres düzeyi arasında anlamlı bir ilișki bildirilmiștir (35). Harris M.L ve arkadașlarının yaptıkları çalışmada ise orta ve 
yüksek stres seviyesindeki artritli kișilerde stres el ve el bileği ağrısı arasında pozitif bir ilișki bulunmuștur (33). Bu çalıșmadaki sonuçlar literatüre benzerlik göstermektedir. Son 7 gün el/el bileği ağrısı ile stres seviyesi arasında anlamlı bulunmuștur. Chang K.C. ve arkadașlarının evde çalıșan göçmen bireylerde yaptıkları çalıșmada son 12 ayda el/el bileği ağrısı yașayanların insidansı \%73,3'tür. Ancak bu çalıșmada el/el bileği ağrısı yașayanlar ve psikolojik faktörler arasında anlamlı bir farklılık bulunmamıștır (34). Bu durumun KisH ile ilișkisi incelenen diğer parametrelerdeki oranın yüksek olmasından ve örneklem sayısının düșük olmasından kaynaklanabileceği düșünülmektedir. Bu çalıșmada da benzer şekilde son 12 ay el/ el bileği ağrısı ve stres düzeyi arasında anlamlı bir ilişki bulunmamıștır.

Stresin neden olduğu en önemli rahatsızlıklardan biri de bel ağrısıdır (36). Literatürde bel ağrısı ve stres arasındaki ilişkiyi inceleyen çalıșmalar bulunmaktadır (37-39). Șimșek Ș. ve arkadașlarının yaptıkları çalıșmada sağlık çalıșanlarında bel ağrısı olan ve olmayan bireylerin algılanan stres seviyeleri arasında anlamlı bir ilișki olduğu bildirilmiștir (37). Chen W.Q. ve arkadașlarının petrol tesisat ișçilerinde yaptıkları bir çalışmada da son 12 ay bel ağrısı ve mesleki stres arasında pozitif bir ilişki bulunmuştur (38). Tsuboi Y. ve arkadașlarının yaptıkları bir çalıșmada yașı bakım çalıșanlarında algılanan stres ve bel ağrısı arasında pozitif ve anlamlı bir ilișki bildirilmiștir (32). Yasobant S. ve arkadaşlarının Hintli sağlık çalışanlarında KiSH ve risk faktörlerinin incelendiği çalıșmada, bel ağrısının en yüksek oranda bulunan rahatsızlık olduğu ancak bel ağrısı ve stres arasında anlamlı bir ilișki bulunmamaktadır (13). Karahan A. ve arkadaşlarının sağlık çalıșanlarında yaptıkları çalıșmada orta ve yüksek seviye stres varlığının bel ağrısı ile iliş̧kili olduğu tespit edilmiştir (39). Bu çalışmadaki sonuçlarda ise son 12 ay ve son 7 gün bel ağrısı ile stres arasında literatürün aksine anlamlı ancak negatif bir ilișki bulunmuștur. Bu durumun sebebinin bel ağrısı geçiren kișilerin strese karșı bir adaptasyon geliștirmiş olabileceği düşünülmektedir.

\section{SONUC}

Bu çalışmada COVID-19 salgınında çalışan sağıı personellerinde el/ el bileği ve bel ağrısının stresle ilișkili olduğuna dair bulunan sonuçlar literatüre katkı sağlayacaktır. Ağrı ile ilișkili diğer faktörlerin araștırıldığı ve popülasyonu daha yüksek çalıșmalara intiyaç bulunmaktadır.

\section{BILDIRIMLER}

Değerlendirme

Dıș danıșmanlarca değerlendirilmiștir.

Çıkar Çatıșması

Yazarlar bu makale ile ilgili herhangi bir çıkar çatıșması

bildirmemișlerdir.

Finansal Destek

Yazarlar bu makale ile ilgili herhangi bir malî destek kullanımı bildirmemișlerdir.
Etik Beyan

Bu çalışma için Gümüşhane Üniversitesi Bilimsel Araștırma ve Yayın Etiği Kurulundan 05.05.2020 tarih ve 2020/5 sayılı yazı ile izin alınmıș olup Helsinki Bildirgesi kriterleri göz önünde bulundurulmuștur.

\section{KAYNAKLAR}

1. Huang $\mathrm{X}$, Wei $\mathrm{F}, \mathrm{Hu}$ L, et al. Epidemiology and clinical characteristics of COVID-19. Archives of Iranian medicine. 2020;23:268-71. https://doi.org/10.34172/aim.2020.09

2. Wu J, Liu J, Zhao X, et al. Clinical characteristics of imported cases of COVID-19 in Jiangsu province: a multicenter descriptive study. Clin Infect Dis. 2020;71:706-712. https:// doi.org/10.1093/cid/ciaa199

3. WHO. https://www.who.int/emergencies/diseases/novelcoronavirus-2019 2020. Erișim tarihi 10.02.2021

4. Sağlık Bakanlığı TCS. https://covid19.saglik.gov.tr/. 2020. Erişim tarihi 10.02.2021

5. Huang C, Wang Y, Li X, et al. Clinical features of patients infected with 2019 novel coronavirus in Wuhan, China. The lancet. 2020;395:497-506. https://doi.org/10.1016/S01406736(20)30183-5

6. Formica S, González-García C, Senoussi M, et al. Neural Oscillations Dissociate Between Maintenance And Proceduralization of Novel Instructions. bioRxiv. 2020:1-43. https://doi.org/10.1016/j.neuroimage.2021.117870

7. Ayittey FK, Dzuvor C, Ayittey MK, et al. Updates on Wuhan 2019 novel coronavirus epidemic. Journal of Medical Virology. 2020;92:403. https://doi.org/10.1002/jmv.25695

8. Lee AM, Wong JG, McAlonan GM, et al. Stress and psychological distress among SARS survivors 1 year after the outbreak. The Canadian Journal of Psychiatry. 2007;52:233-40. https://doi. org/10.1177/070674370705200405

9. Li W, Yang Y, Liu Z-H, et al. Progression of mental health services during the COVID-19 outbreak in China. International journal of biological sciences. 2020;16:1732. https://doi. org/10.7150/ijbs.45120

10. Bair MJ, Wu J, Damush TM, et al. Association of depression and anxiety alone and in combination with chronic musculoskeletal pain in primary care patients. Psychosomatic medicine. 2008;70:890. https://10.1097/PSY.0b013e318185c510

11. Buscemi V, Chang W-J, Liston MB, et al. The role of perceived stress and life stressors in the development of chronic musculoskeletal pain disorders: A systematic review. The Journal of Pain. 2019;20:1127-39. https://doi.org/10.1016/j. jpain.2019.02.008

12. Blackburn Munro G, Blackburn Munro R. Chronic pain, chronic stress and depression: coincidence or consequence? Journal of neuroendocrinology. 2001;13:1009-23. https://doi. org/10.1046/j.0007-1331.2001.00727.x 
13. Yasobant S, Rajkumar P. Work-related musculoskeletal disorders among health care professionals: A cross-sectional assessment of risk factors in a tertiary hospital, India. Indian journal of occupational and environmental medicine. 2014;18:75. https://doi.org/10.4103/0019-5278.146896

14. Keskin, B. İstatistiksel Güç Bir Araștırmanın Sonuçlarına Etki Eder Mi? Örneklem Büyüklügüune Nasıl Karar Verilmeli?. Manisa Celal Bayar Üniversitesi Sosyal Bilimler Dergisi; 2020;18(Armağan Sayısı), 157-174. https://doi.org/ 10.18026/ cbayarsos.644692

15. Cohen S, Kamarck T, Mermelstein R. A global measure of perceived stress. Journal of health and social behavior. 1983;24:385-96. https://doi.org/10.2307/2136404

16. Eskin M, Harlak H, Demirkıran F, ve ark. Algılanan stres ölçeğinin Türkçeye uyarlanması: güvenirlik ve geçerlik analizi. New/Yeni Symposium Journal; 2013;51;132-140

17. Kahraman T, Genç A, Göz E. The Nordic Musculoskeletal Questionnaire: cross-cultural adaptation into Turkish assessing its psychometric properties. Disability and rehabilitation. 2016;38:2153-60. https://doi.org/10.3109/09638288.2015.11 14034

18. Kuorinka I, Jonsson B, Kilbom A, et al. Standardised Nordic questionnaires for the analysis of musculoskeletal symptoms. Applied ergonomics. 1987;18:233-7. https://10.1016/00036870(87)90010-x

19. Jang T-W, Koo J-W, Kwon S-C, etal. Work-related musculoskeletal diseases and the workers' compensation. Journal of Korean medical science. 2014;29:S18-S23. https://10.3346/ jkms.2014.29.S.S18

20. Briggs AM, Bragge $P$, Smith AJ, et al. Prevalence and associated factors for thoracic spine pain in the adult working population: a literature review. Journal of occupational health. 2009;51:177. https://10.1539/joh.k8007

21. Akbaba YA, Yeldan I, Kuru T, ve ark. Ofis çalışanlarında omurga ağrısı üzerine cinsiyetin etkisi. Cerrahpaşa Tıp Dergisi. 2009;40:121-8.

22. Skovlund SV, Bláfoss R, Sundstrup E, et al. Association between physical work demands and work ability in workers with musculoskeletal pain: Cross-sectional study. BMC Musculoskeletal Disorders. 2020;21:1-8. https://10.1186/ s12891-020-03191-8

23. Davis KG, Kotowski SE. Prevalence of musculoskeletal disorders for nurses in hospitals, long-term care facilities, and home health care: a comprehensive review. Human factors. 2015;57:754-92. https://doi.org/10.1177/0018720815581933

24. McBeth J, Jones K. Epidemiology of chronic musculoskeletal pain. Best practice \& research Clinical rheumatology. 2007;21:403-25. https://doi.org/10.1016/j.berh.2007.03.003
25. Sirzai H, Dogu B, Erdem P, ve ark. Hastane Çalisanlarinda Ise Bagli Kas Iskelet Sistemi Hastaliklari: Üst Ekstremite Problemleri/Work-related musculoskeletal diseases in hospital workers: Upper extremity problems. Șişli Etfal Hastanesi Tip Bülteni. 2015;49:135. https://doi.org/10.5350/ SEMB.20141202054038

26. Cohen S, Janicki-Deverts D, Miller GE. Psychological stress and disease. Jama. 2007;298:1685-7. https://doi.org/10.1001/ jama.298.14.1685

27. Bayrak B, Oğuz S, Arslan S, ve ark. Miyokard Infarktüsü Geçirmiş Hastalarda Algılanan Stresin Belirlenmesi. Turk J Cardiovasc Nurs. 2019;10:129-37. https://doi.org/10.5543/ khd.2019.09719

28. Cimmino MA, Ferrone C, Cutolo M. Epidemiology of chronic musculoskeletal pain. Best practice \& research Clinical rheumatology. 2011;25:173-83. https://doi.org/10.1016/j. berh.2010.01.012

29. Savci M, Aysan F. Üniversite öğrencilerinde algılanan stres düzeyi ile stresle başa çıkma stratejileri arasındaki ilișki. Uluslararası Türk Eğitim Bilimleri Dergisi. 2014;2014:44-56.

30. Atanes AC, Andreoni S, Hirayama MS, et al. Mindfulness, perceived stress, and subjective well-being: a correlational study in primary care health professionals. BMC complementary and alternative medicine. 2015;15:303. https://doi.org/10.1186/s12906-015-0823-0

31. Tekin E, Çilesiz ZY, Selçuk G. Farklı mesleklerde çalışanların algılanan stres düzeyleri ve stresle başa çıkma tarzları üzerine bir araştırma. ODÜ Sosyal Bilimler Araştırmaları Dergisi (ODÜSOBIAD). 2019;9:79-89.

32. Tsuboi $Y$, Ueda $Y$, Naruse $F$, et al. The association between perceived stress and low back pain among eldercare workers in Japan. Journal of occupational and environmental medicine. 2017;59:765-7. https://doi.org/10.1097/ JOM.0000000000001062

33. Harris ML, Loxton D, Sibbritt DW, et al. The influence of perceived stress on the onset of arthritis in women: findings from the Australian Longitudinal Study on women's health. Annals of Behavioral Medicine. 2013;46:9-18. https://10.1007/ s12160-013-9478-6

34. Chang K-C, Liao Y-H, Lee H-C, et al. Musculoskeletal disorders, psychosocial stress and associated factors among homebased migrant care workers. Work. 2020:1-13. https://doi. org/10.3233/WOR-203119

35. Mehrdad R, Dennerlein JT, Haghighat M, et al. Association between psychosocial factors and musculoskeletal symptoms among Iranian nurses. American journal of industrial medicine. 2010;53:1032-9. https://doi.org/10.1002/ ajim.20869

36. McFarlane AC. Stress-related musculoskeletal pain. Best Practice \& Research Clinical Rheumatology. 2007;21:549-65. https://doi.org/10.1016/j.berh.2007.03.008 
37. Simşek Ş, Yağcı N, Şenol H. Prevalence and risk factors of low back pain among health-care workers in Denizli. AğrıThe Journal of The Turkish Society of Algology. 2017;29:71-8. https://doi.org/10.5505/agri.2017.32549

38. Chen W, Yu IT, Wong T. Impact of occupational stress and other psychosocial factors on musculoskeletal pain among Chinese offshore oil installation workers. Occupational and environmental medicine. 2005;62:251-6. https://doi. org/10.1136/oem.2004.013680
39. Karahan A, Kav S, Abbasoglu A, et al. Low back pain: prevalence and associated risk factors among hospital staff. Journal of advanced nursing. 2009;65:516-24. https://doi. org/10.1111/j.1365-2648.2008.04905.x 